\title{
The Cyprus Obstacle on Turkey's Road to Membership in the European Union
}

\author{
SEMIN SUVARIEROL
}

Turkish-Greek relations and the Cyprus problem following the Turkish intervention of 1974 have occupied an important place throughout the evolution of the relations between Turkey and the European Union (EU). ${ }^{1}$ These two issues, often linked, figured among the most difficult to handle. The fact that Greece became a member of the EU in 1981 has complicated matters further, especially for the EU. From that point on, the EU could no longer keep its benevolent neutrality towards its two allies. Consequently, the road towards the amelioration of Turkish-EU relations passed via Athens and Nicosia, ${ }^{2}$ despite Turkey's desire to keep the resolution of these issues separate from the question of its accession to the EU.

The divided island of Cyprus constitutes one of the "thousands of problems" the current EU enlargement process entails as a whole. ${ }^{3}$ Each candidate obviously has its own particular problems; yet, even a brief look at the list of candidate countries may indicate that the case of Cyprus is the most exceptional case at present. The paradox is that, at the economic and administrative level, Cyprus is the best candidate. It is the most prosperous among the candidate countries and has all the administrative structures necessary for membership. But which Cyprus? Due to the Cyprus conflict, which has remained unresolved for 39 years, this preoccupying question has framed the Cypriot case as a politically problematic candidacy.

The link between the Cyprus issue and the accession of Turkey to the EU has become especially pronounced since Cyprus and Turkey both became candidates for EU membership. As a result of the European Council's 1999 Helsinki summit decisions, the resolution of the Cyprus problem is not a precondition to the accession of the Republic of Cyprus (RoC) or Turkey to the EU. Nevertheless, Ankara is expected to play an active role in bringing about a settlement in Cyprus as all parties concerned perceive it as having a key part in achieving the resolution of this imbroglio. Given this expectation and the noting of this issue as a short-term priority of Turkey's Accession Partnership, Cyprus is a sine qua non for Turkey's membership. Turkey thus finds itself obliged to modify 
its stance on this issue if it truly wants to become a part of the EU and to contribute to the stability of the region and the wellbeing of Cypriots.

This contribution does not aim to analyze the details of the Cyprus problem. In order to assist the reader and provide context, a chronology of the key events in the history of Cyprus, including the major turning points of Cyprus' and Turkey's relations with the EU, appears at the end of this piece. This contribution aspires to show how and why it is in Turkey's best interest to see Cyprus join the EU once a settlement is reached. As the Greek Cypriots will be accepted to the Union even without a settlement, an eventuality that may potentially trouble Turkey's own European course, Ankara will benefit from an early, rather than late, settlement. First, the Cyprus policies of Turkey and the EU will be examined in detail. Next, the Greek influence on the shaping of the European attitude will be emphasized, followed by a depiction of the links between the Turkish and Cypriot accessions to the EU and an anticipation of what lies ahead in the near future. ${ }^{4}$

\section{TURKISH POLICY ON CYPRUS}

Turkish policy on Cyprus is quite paradoxical. On one hand, Cyprus remains a national cause (milli dava) and a bastion of strategic interests for Turkey. On the other hand, Turkey argues that the resolution of the Cyprus problem is the sole responsibility of Greek and Turkish Cypriots. As a result of this double-edged policy, Turkey finds itself simultaneously demanding that its interests be taken into account with regard to any decision regarding Cyprus and denying it has any role in bringing about a solution in Cyprus, apart from declaring that it encourages all efforts to reach a settlement.

Why is Cyprus a national cause for Turkey? As an ancient Ottoman territory, Cyprus has historical significance for Turkey. There is thus a sense of national solidarity towards the Turkish Cypriots, similar to that felt towards other Turkish populations previously under Ottoman rule. Turkish presence on the island symbolizes and guarantees the upholding of Turkish interests, which are predominantly of strategic value. Only 40 nautical miles away from Anatolian coasts, the extension of the Karpaz peninsula offers Cyprus the possibility of blocking the exit from the gulf of Iskenderun and thus threatens Turkey's naval maneuverability. ${ }^{5}$ For this reason, Cyprus is perceived as a dagger aiming at the stomach of Turkey. This rather outdated military vision (outdated when one considers the current technological circumstances) dominates the handling of the Cyprus issue by Ankara. Beyond this rhetoric, the strategic significance of Cyprus 
seems to currently lie in the fact that it is basically a "stationary aircraft carrier" (sabit uçak gemisi). ${ }^{6}$ There is also the argument that the loss of Cyprus to Turkey's historical enemy, Greece, signifies a threat against vital Turkish interests. If Cyprus became "Greek," the Anatolian coasts would be encircled by a string of Greek islands. Consequently, the balance of forces between Greece and Turkey would be destroyed, the safeguarding of which is always of great psychological importance for Turkey. ${ }^{7}$

It was these considerations which brought about the Turkish intervention of 1974, rather than the humanistic pretext of the protection of the Turkish Cypriot minority. This strategic bastion has to be preserved in one way or another at all costs. Prime Minister Bülent Ecevit, a staunch hardliner on the Cyprus issue, is said to have claimed in 1998 that Cyprus is so indispensable for the strategic interests of Turkey that Ankara would not withdraw its troops even if there were not a single Turkish Cypriot living on the island. ${ }^{8}$ Therefore, compromises on the rights of Turkey over Cyprus are out of the question. In addition, it is the first territory won against the enemy, the first contemporary victory of the Turkish army and the first expression of the determination of Turkey to protect its interests and to display publicly its strategic priorities. ${ }^{9}$ Consequently, none of the political parties dare to make far-reaching concessions on Cyprus - an issue with high nationalistic connotations-for whatever objective it may be. Decisions like the compromise of March 6, 1995, which guaranteed Cyprus that its accession negotiations will begin six months after the conclusion of the 1996 IGC (Intergovernmental Conference) in return for the lifting of the Greek veto on the customs union agreement with Turkey, provoked comments such as "Cyprus has been sold" from the public and media. Turkish nationalists especially emphasize that compromising on Cyprus would trigger losses of other vital interests of the country.

\section{Turkish Reaction to the Republic of Cyprus'Application for EU Membership}

When the Republic of Cyprus applied for membership to the EU in 1990, Turkish leaders were alarmed. The Greek presence in the EU already prevented the amelioration of relations between Turkey and Europe, and now the Greeks would obtain a second veto against Turkey, in addition to their own. The balance established by the treaties founding Cyprus was being threatened.

Turkey insisted that the Cypriot application, as such, should be unacceptable to the EU. Consequently, Turkey requested the advice of experts on international law, namely Maurice H. Mendelson ${ }^{10}$ and Christian Heinze, ${ }^{11}$ to convince Europe and the rest of the international community that the Greek Cypriot application was against principles of international 
law, which the EU claims to always respect. Mendelson pointed to Article 185 of the Constitution of the Republic of Cyprus - an "unamendable" disposition-which stipulates, "The integral or partial union of Cyprus with any other State is excluded." He argued that the intention of the treaties establishing the Republic of Cyprus was to prevent the possibility of giving Greece or Turkey a more favorable economic position on the island which would amount to an economic enosis (unification of Cyprus with Greece). For this reason Article 8 of the Constitution underlined that "The President and the Vice President separately or conjointly, shall have the right of final veto on any law or decision concerning foreign affairs, except the participation of the Republic of Cyprus in international organizations and pacts of alliance in which Greece and Turkey both participate." This was interpreted as the president and the vice president having a veto right on the accession of Cyprus to organizations of which only one of these two states was a member, which of course would include the EU. Mendelson concluded that the Greek Cypriot administration had no right to apply for membership to the EU nor could it become a member as long as Turkey remained outside the EU.

These arguments, however, have not succeeded in persuading the European Union, since it interpreted the Cyprus question differently. Furthermore, for EU officials, the issue of Cyprus' accession is an eminently political debate, and law can adapt itself to any political solution. ${ }^{12}$ On the other hand, Turkey's staunch emphasis on international law with regard to Cyprus has become rather hypocritical following the rulings of the European Court of Human Rights on Cyprus that Turkey still refuses to abide by.

Turkey had hoped that accession negotiations with Cyprus would not be launched before the resolution of the Cyprus conflict. Ankara has stated repeatedly that it neither wants the Union to become involved in the Cyprus question, nor does it approve of the EU having an active role in the negotiations for settlement in Cyprus. As Greece is a member of the EU, Turkey is convinced the Union cannot be impartial. Accordingly, Turkey even resented the appointment of an EU observer to these settlement talks. ${ }^{13}$

When the decision to open accession negotiations with Cyprus was taken simultaneously with the decision to put into force the customs union with Turkey, the prime minister at the time, Tansu Çiller, was fiercely criticized. The opposition parties blamed her government for having agreed to this historical compromise which "sold Cyprus," even though the minister of foreign affairs, Murat Karayalçın, declared during the March 6, 1995 Association Council meeting-where these decisions had been finalized - that Turkey's Cyprus policy had not changed at all. 
This historical compromise by Turkey naturally had repercussions in the Turkish Republic of Northern Cyprus (TRNC). Many Turkish Cypriots had the impression that Turkey could abandon them for the sake of its own interests, seeing the TRNC as but a bargaining card. ${ }^{14}$ To counter this perception, Turkey and the TRNC signed a common declaration on December 28, 1995, which asserted that they only approve the accession of Cyprus to the EU within the framework of a definite solution of the Cyprus problem. The same declaration maintained that the ties between the two countries would be reinforced at the economic and political levels.

Meanwhile, Greece and the Republic of Cyprus launched the "Joint Defense Dogma" in December 1993 with the aim of improving the coordination of the defense of Hellenic space against Turkish expansionism. The Dogma has been put into action through joint military exercises (called Nikiphoros) and the construction of a new air base in Paphos. Alarmed by this attempt to change the balance of power in the region, the Turkish government protested vigorously when the Republic of Cyprus announced its decision to purchase Russian S-300 missiles with a range of $150 \mathrm{~km}$ in January $1997 .{ }^{15}$ These missiles have been perceived as a direct threat to the security of Turkey, and the Turkish army has indicated that the move will be perceived as a casus belli and threatened preventive bombing should the missiles be deployed in Cyprus. ${ }^{16}$

The common declaration of January 20, 1997, signed between Turkey and the TRNC, was orchestrated within this context. The two parties were convinced that the Greek Cypriots aimed for indirect enosis through membership in the EU. To restore balance, they announced their intention of creating a concept of common defense: any attack against the TRNC would be considered an attack on Turkey. Furthermore, the declaration warned, "All steps taken by the Greek Cypriot Administration towards accession to the EU will accelerate the integration of the TRNC with Turkey." ${ }^{17}$

Similar declarations followed, finally resulting in an agreement on August 6, 1997, establishing the Association Council between Turkey and the TRNC, engineering partial integration at the economic, military and foreign policy levels. When the European Council Luxembourg summit declared that the EU would start accession negotiations with Cyprus and excluded Turkey from the list of candidates for the next wave of EU enlargement, the TRNC President Rauf Denktaş and Mesut Y1lmaz, the Turkish prime minister of the time, firmly indicated that this decision left them a single option: integration. The TRNC followed Turkey's path of breaking off all contacts with the EU. Symbolically, the first meeting of the Association Council between Turkey and the TRNC took place on March 
31, 1998, the day the EU began accession negotiations with the Republic of Cyprus.

Gradually, the Turkish stand moved further away from the idea that the solution of the Cyprus problem should be through the formation of a federation. The Turkish and Turkish-Cypriot governments started stating openly that the two sovereign states on the island should be recognized. This position, relatively softened with the proposition of Rauf Denktaş in favor of establishing a Cypriot federation, was made public on August 31, 1998. Turkey gave this proposition full support with a common declaration on July 20,1999. ${ }^{18}$ All these acts were a manifestation of Turkish foreign policy that proclaims itself as reactive, in the sense that it is formed as a response to positions taken by Greece, the Republic of Cyprus, and the EU. Turkey argued that since these three had modified all the parameters of the Cyprus question, Turkey and the TRNC could do the same. ${ }^{19}$

When the Agenda 2000 and the European Council Luxembourg summit Declaration excluded Turkey even from the list of candidates for the second round of enlargement, this provoked an outcry in Turkey. The $\mathrm{EU}$, aware of the risk of alienating Turkey by excluding it from the list of candidates, had invited it to the European Conference to show that Turkey would one day become a candidate for membership. However, Turkish leaders were offended by the text of the Presidency Conclusions of the Luxembourg summit referring to the European Conference which underlined the following:

The members of the Conference must share a common commitment to peace, security and good neighborliness, respect for other countries' sovereignty, the principles upon which the European Union is founded, the integrity and inviolability of external borders and the principles of international law and a commitment to the settlement of territorial disputes by peaceful means, in particular through the jurisdiction of the International Court of Justice in the Hague. Countries which endorse these principles and respect the right of any European country fulfilling the required criteria to accede to the European Union and sharing the Union's commitment to building a Europe free of divisions and difficulties of the past will be invited to take part in the Conference. ${ }^{20}$

This diplomatic formulation, which conditioned the participation in the Conference to a commitment to these principles, troubled Turkish national pride. Basically, the EU was imposing what it considered as the viable solution to Greek-Turkish problems and the Cyprus issue. It was also pressing forward the idea that Cyprus could accede to the Union once it 
fulfilled the accession criteria. Yet, the Turkish government was convinced that the decisions on these issues concerned Turkey alone. The EU should not encroach upon the sovereignty of the country. Above all, it should not interfere with issues considered of critical national importance. As a result, Turkey categorically refused all the above conditions and did not participate in the European Conference.

The strategies developed by the EU exclusively for Turkey, namely the French idea of assembling all the candidate countries at the European Conference, proved insufficient for overcoming the resentment of Turkish leaders. Ankara cut off all political dialogue with the EU until the Union abandoned what the Turkish officials saw as its discriminatory attitude towards Turkey, and waited for the EU to correct its "historical error." This long-awaited day came with the Helsinki summit, when Turkey finally became the thirteenth candidate for accession.

Prior to the Helsinki summit, the EU strategy had been to pressure Turkey by highlighting that Turkish-EU relations could be improved if, among other conditions, Turkey contributed to a resolution of the Cyprus question that would reunite the island and lead to the accession of Cyprus to the EU. This strategy would surely help to resolve the Cyprus question, as well as the problems related to the accession of Cyprus to the EU, if Turkey acknowledged that the revision of its policy on Cyprus constituted virtually a precondition for its own accession. Turkey, however, has refused viewing the revision of its policy on Cyprus as a precondition and, to the contrary, has taken measures towards closer integration with the TRNC. The fact that it felt alienated by the EU has therefore complicated matters further in Cyprus.

\section{The 1999 Helsinki Summit and its Aftermath}

As the strategy of excluding Turkey from the list of candidates only caused the hardening of the Turkish position, the EU changed its policy towards Turkey by announcing Turkey's official candidacy for membership at the European Council Helsinki summit. It was hoped that Turkey's accession process would also contribute to the resolution of the Cyprus problem. The expectation was that Turkey, as one of the major actors in Cyprus, would modify its position to break the deadlock on the island. Yet, Turkish politicians still tend to separate the Cyprus problem from the issue of Turkey's EU membership, mainly due to domestic political concerns.

The ambiguous language of the Helsinki conclusions initially led Turkish leaders to mistakenly believe that the EU would not undermine Turkey's interests, so that when the time came the EU would not let the Greek Cypriots join without the resolution of the Cyprus question. When the President of the European Commission, Romano Prodi, made it clear 
during his visit to the Republic of Cyprus in October 2001 that Cyprus would be among the first wave of EU members, irrespective of a political settlement, there was finally a realization that "the Cyprus issue was not going well for Turkey." ${ }^{21}$ This acknowledgment was accompanied by a recourse to threats: the Turkish Minister of Foreign Affairs at the time, İsmail Cem, declared that "Turkey might be forced to take drastic measures" in the event of a Greek Cypriot accession prior to an agreement on the Cyprus question..$^{22}$ This was followed by statements by Prime Minister Ecevit that Turkey could annex the TRNC if the EU admitted Cyprus before a settlement. ${ }^{23}$

These unexpected threats led an EU Commission spokesman to express regret over the hardening tone and warned that annexation of Northern Cyprus would probably jeopardize Ankara's own hopes of joining the EU..$^{24}$ The European Parliament had already made it clear in its report published in July 2001 that "if Turkey were to carry out its threat of annexing the north of Cyprus in response to Cypriot accession to the EU and to proclaim the northern part as its 82 nd province in clear breach of international law, it would put an end to its own ambitions of European Union membership." ${ }^{25}$ This tension has relatively declined with the opening of direct talks between the two community leaders in Cyprus.

\section{THE CYPRUS POLICY OF THE EU AND THE GREEK FACTOR}

Whereas Turkish politicians have concerns (mentioned above) which shape Turkish policy on Cyprus, the EU has had its own internal considerations and precedents that generated its Cyprus policy. First, EU members in general seek to use the enlargement process for promoting their own interests or for exteriorizing their interior problems. ${ }^{26}$ That said, Cyprus presents a fundamental political interest for an EU member: Greece. Greece has utilized all possible instruments within the EU to support the membership application of Cyprus. Even though Greece is a small country in the Union it has managed to make its voice heard concerning issues of importance for Greek foreign policy. ${ }^{27}$ Wielding the veto stick in the Council of Ministers, Athens has influenced EU policy $v i s-\grave{a}$-vis Cyprus. The Greek influence can be described as a negative influence as this influence has led the EU, at times, to take certain unwanted decisions. ${ }^{28}$ However, this claim is rejected by Greek diplomats, who point out that Greece has not been confronted with any pressure to refrain from using its right to veto. ${ }^{29}$

Nevertheless, as the EU machinery functions on compromise, the EU has managed to balance this negative influence by linking every 
compromise made to Greece to a compromise by Greece on other issues that the EU wanted to press forward. Thus, each substantial success that Greece has obtained towards the progress of the Cypriot candidature was a result of a compromise it made regarding the progress of the Turkish candidature. Even though the EU had hoped that Greece's accession would not affect Turkey-EU relations,${ }^{30}$ the functioning of EU organs constrains the EU sphere of action. No one can say that Greece has no right to insist on issues concerning its national interests because this is the right of each EU member state.

In principle, though, the EU has always sought to maintain a balanced approach towards its two allies, Greece and Turkey, by avoiding involvement in Greek-Turkish conflicts. This benevolent neutrality is notably observable in the fact that the Association Agreement with Greece was followed by the Association Agreement with Turkey. Allegedly, once Greece applied for membership to the EU, Turkey was encouraged to follow suit in order to safeguard the equal treatment of these two NATO allies - although this recommendation was not undertaken by the Turkish government at the time. Consequently, when Athens joined the EU in 1981, the Community found itself inevitably drawn into the relations between these two countries. ${ }^{31}$ From that point on, the Community was obliged to be careful in order not to push Turkey away from Europe, or the West in general, which would have had undesirable consequences (especially during the cold war). This cautious policy prevented it from taking a firmer stance towards Turkey, even if it continued to deplore the Turkish military presence in Cyprus. The cost of sanctions, for example, would be too high. As long as Turkey remained outside, the EU could afford to be more flexible in order to preserve its ally.

Once Turkey and Cyprus materialized their European vocations through their applications for membership, the Community developed its Cyprus policy. ${ }^{32}$ The European Parliament had notably adopted several resolutions conveying that the solution of the Cyprus problem would lead to the amelioration of the relations between the EU and Turkey. ${ }^{33}$ The December 1989 opinion of the European Commission on the Turkish application also stated resolutely that the evaluation of the political aspects of the application would be incomplete if it did not take into consideration the negative effects of the disagreements between Turkey and a member state (Greece), but also the situation in Cyprus. Thus, the Cyprus problem had to be resolved if Turkey genuinely wanted to join the EU.

Once it became evident that the Cyprus policy of Turkey was incompatible with its vocation to join the Community, the fact that Turkey did not alter this policy not only allowed Greece to gain the support of its 
European partners but also reflected the non-credibility of the European orientation of Turkey. ${ }^{34}$ Meanwhile, three developments during the $1980 \mathrm{~s}$ forced the Community to take a more activist position regarding Cyprus: $:^{35}$

- The accession of Greece to the EU;

- The denunciation by the Greek Cypriot political elite of enosis as a political objective (November 1981);

- The progressive consolidation of the Turkish Cypriot administration as a separate state.

The accession of Greece has rendered the option of enosis obsolete as the annexation of Cyprus by Greece would clearly violate the sovereignty of an associated state by a member state. ${ }^{36}$ The viability of the Cypriot state was hence reinforced. As a result, the pro-enosists in Greece and Cyprus were weakened, which allowed the removal of enosis from the agenda of the Greek Cypriot government. The EU has therefore willingly let Greece Europeanize the Cyprus question. After all, while the enosis option ceased to exist, the occupation of the Turkish army remained. ${ }^{37}$

Turkey, however, has chosen to blame the influence of Greek pressure and has accused the EU of submission to Greek blackmail. Particularly because of the three developments aforementioned, there were many other voices within the Union favoring a more activist position, as advanced by Greece. ${ }^{38}$ Yet, on each relevant occasion, Ankara severely criticized the European stance on Cyprus, repeating that it had not occupied Cyprus. In Turkey's eyes, the EU persisted in its erroneous assessment of the Cyprus question and thus adopted a Cyprus policy based on the Greek view. ${ }^{39}$

The Greek Presidency of the EU had already established during the Corfu summit in 1994 that the next enlargement would include Cyprus. However, the "historical compromise" of 1995 marked the beginning of the give-and-take process on Cyprus. ${ }^{40}$ During the 1997 Luxembourg summit, it has been claimed that Greece again asserted that it would only approve the list of the first-wave candidates if Cyprus was included and negotiations with it would begin. ${ }^{41}$ One eurocrat claims that this Greek influence was the only reason the EU started accession negotiations with Cyprus, denying analyses which argue that the Union wanted to increase its political role by contributing to the resolution of the Cyprus conflict. ${ }^{42}$

While the accession negotiations with the $\mathrm{RoC}$ moved forward successfully, there was no progress on the resolution of the Cyprus problem. To the contrary, the inter-communal talks which broke down in 1997-under the Turkish Cypriot party's pretext of the European Council's decision to open accession negotiations with Cyprus-were interrupted until December 1999. It is in this context that the new Helsinki package was orchestrated in order to obtain Greek agreement to 
Turkey's candidacy. ${ }^{43}$ The European Council of Helsinki, while welcoming the launch of the talks aiming at a comprehensive solution of the Cyprus problem and underlining that a political settlement will facilitate the accession of Cyprus to the European Union, concluded: "If no settlement has been reached by the completion of accession negotiations, the Council's decision on accession will be made without the above being a precondition. In this the Council will take account of all relevant factors." ${ }^{44}$

While the European Union still bases its position with regard to Cyprus' accession on the Helsinki decisions, the conclusions of the June 21-22, 2002 Seville European Council confirmed that the EU's preference continues to be for the accession of a reunited island. ${ }^{45}$ Yet, if the current negotiations in Cyprus fail, the undesirable eventuality of the accession of a divided Cyprus appears predictable. Any other option would endanger the entire enlargement project: Greece repeats its threat of vetoing the accession of Central and East European states in the event that Cyprus is excluded from the first wave of enlargement. ${ }^{46}$ Greece's argument refers to the accession criteria, emphasizing that a candidate who fulfills these cannot be prevented from joining the Union. Thus, if the EU is a community of values, the exclusion of Cyprus will not be morally justifiable. Clearly, this argument is highly valid for the EU, which aspires to function according to well-established principles. Yet again, it can be recalled that the EU had asked the Central and Eastern European countries to settle their minority and border disputes through the Balladur Stability Pact before accession. Still, settling the Cyprus problem is not a condition that the RoC has to fulfill, as stated in the Helsinki decisions. This means that the EU will be accepting a state that claims to be occupied and therefore unable to apply accession criteria to those occupied territories. The EU, then, can obviously be selective on what set of principles or criteria to apply for a given case, according to its interests, which makes the moral argument advanced in European circles questionable.

The truth is, since the Eastern enlargement constitutes a major interest for all EU members, they do not want to see the entire process blocked because of a small Mediterranean island. Moreover, at the moment of the first round of enlargement, there will be a package of candidate states. The EU may continue to say that since the Helsinki summit it has adopted the principle of evaluating each candidate on its own merit. However, at the end of the day, this appears to be more rhetorical than what will happen in practice. As in the past, the EU prefers the accession of a group of countries to single accessions. Therefore, when the moment comes, even the member states that are reticent regarding the accession of a divided 
Cyprus will not be able to vote against the accession of Cyprus when they wish to see other candidates accede.

\section{THE LINKS BETWEEN THE TURKISH AND CYPRIOT ACCESSIONS}

The compromise packages made so far concerning Turkey and Cyprus confirm the linkage between the Turkish and Cypriot candidatures for membership to the EU. Although Turkey cannot block the accession of Cyprus to the EU by refusing to contribute to the resolution of the Cyprus conflict, this strategy would jeopardize the accession of Turkey, as well as the accession of Turkish Cypriots. Therefore, the status quo is only to the benefit of the Greek Cypriots, who will be able to join the EU even if the Cyprus problem is not settled. Consequently, instead of having mixed Cypriot delegations within EU organs and the voice of Turkish Cypriots in favor of Turkey, there will be Greek Cypriot officials insisting on more EU pressure on Turkey, especially regarding Cyprus issues. It is likely that the Greek Cypriot government will not be favourable towards Turkey's membership of the EU.

Greek and Turkish Cypriots, as well as EU officials, list such key arguments demonstrating that it is in the interest of Turkey to see the settlement of the Cyprus problem. After all, Cyprus - as an EU memberwould not threaten the strategic interests of Turkey in any way. Accordingly, they are convinced that Turkey would not sacrifice the prospect of its membership because of the Cyprus problem.

On the other hand, the fact that the progress of the Cypriot and Turkish applications was made through compromising should not give the impression that Cyprus is a valuable bargaining card in Turkey's hands. Although Turkey's contribution to the reunification of the island will definitely improve its relations with Europe, as well as with Greece, unification alone will not guarantee Turkish membership in the EU. Cyprus is only one of the short-term priorities included in the Accession Partnership with Turkey. As a matter of fact, the withdrawal of Turkish troops from Northern Cyprus is the minimum price Turkey will be required to pay, ${ }^{47}$ as "it is inconceivable in a community based on the rule of law that one Member State should station troops in part of the territory of another Member State without the explicit agreement of the latter." ${ }^{48}$ No one denies that Turkey is an important partner whose degree of satisfaction matters to the EU, but it should not abuse the Cypriot card. ${ }^{49}$ The decision at Helsinki stipulating that the resolution of the Cyprus problem would not constitute a precondition to the accession of Cyprus signaled precisely that to Turkey. Some predict that an encouraging move towards Turkey will 
take place if Ankara works toward improving the situation in Cyprus, but this move will not be accession to the Union, ${ }^{50}$ contrary to Turkish hopes.

However, many Turkish politicians do not agree with these arguments. There is a tendency in general to overestimate the influence of Turkey. There is also a belief that realpolitik requires that the EU take Turkey's opinions into consideration; otherwise, Europe will have to face the consequences. ${ }^{51}$ Furthermore, strategists continue to claim that Cyprus is of primary strategic importance, especially since the construction project of the Baku-Ceyhan pipeline makes the security of this part of the Mediterranean even more vital than before.

If Turkey has managed to maintain its Cyprus policy since 1974, at the risk of alienating its allies, ${ }^{52}$ it should not compromise now. If Turkey is to renounce its rights on Cyprus, that should only be done in exchange for an important gain, that is, membership to the EU. Yet Euro-skeptics in Turkey claim that the EU will never admit Turkey to its ranks; therefore, there is no need to concede regarding Cyprus, hoping that this would bring Turkey closer to Europe. Jean-François Drevet argues that Turks have an interest in keeping their "booty," selling it for the best price when the time comes..$^{53}$ If the Europeans do not want Turkey's accession, the island could indefinitely remain hostage, according to Drevet, who points out thatparadoxically - its candidature could lead Turkey to stick more vehemently to its conquest. As for the official Turkish foreign policy line on Cyprus, it constantly insists that Turkey does not consider the Cyprus issue a precondition to stronger relations with the EU. Therefore, in Turkey there is either an overestimation or an underestimation of the role of the Cyprus question on Turkish-EU relations.

It is clear that Turkey's attitude towards a potential settlement in Cyprus counts considerably. It is unclear to outside observers to what extent the TRNC authorities are dependent on, or independent from, Turkish authorities when it comes to decisionmaking regarding the fate of Turkish Cypriots. Nevertheless, given that the Turkish army and Turkish economic support constitute the most important bases of power for the TRNC, Turkish Cypriots would obviously have even more incentive for arriving at a settlement should Turkey pressure the TRNC. At the very least, if Turkey gave a clear and unambiguous signal that it wants to see the Cyprus problem solved - instead of merely declaring support for the negotiations - it would give a strong impetus to the talks on Cyprus. Such a clear message would also refute the Greek Cypriot argument that Turkey and the TRNC are intransigent and do not genuinely want a solution in Cyprus. 


\section{CONCLUSION}

The dialogue of the deaf between the Union and Turkey with regard to Cyprus has continued despite overtures made to Turkey, which began at Helsinki. ${ }^{54}$ The EU insists that the pre-accession strategy for Turkey is closely linked to the improvement of Greek-Turkish relations and the resolution of the Cyprus problem. Turkey is adamant that its Cyprus policy remains the same: the Cyprus problem belongs to the two communities on the island and is theirs to solve. As Turkish leaders insist on Turkey's sensitivities, so the EU insists on its own interests. The EU does not accept a third party blocking the accession of Cyprus, which means it will not accord a voice to Turkey on this issue. Europe is wary not to create precedents which could possibly open the way for other third countries to claim a similar right concerning their national interests.

If the EU is convinced that Turkey is capable of contributing to the solution of the Cyprus problem it is because of the well-founded conviction that Turkey has decisive leverage on the TRNC. Given its close political ties and dialogue with the Turkish Cypriot community, Turkey has more capacity to make itself heard in Northern Cyprus than any other actor ${ }^{55}$ The Turkish Cypriots are also aware of this strong Turkish influence, and they judge that the prospect of the EU membership will eventually oblige Turkey to work for a solution in Cyprus. Turkish Cypriots have thus welcomed the Helsinki decisions, as many of them believe that Turkey will preserve Cyprus as a bargaining card until its own accession. ${ }^{56}$ It is therefore essential that Turkey dedicates itself to preparing for its own membership so that it could start its accession negotiations as soon as possible.

Certainly, symbolic declarations of support for the talks in Cyprus are important, but it is time that Turkey effectuate a fundamental change of attitude and policy regarding Cyprus. Furthermore, Turkey's threats of annexing the TRNC are not regarded as credible by the Greek Cypriots or in Europe, as Turkey has used this diplomatic arm before to push for its national interests. This recourse to threats is rather a self-defeating policy for Turkey as enforcing them will demand a high price, which brings into question the actual credibility of these threats and, therefore, largely renders them ineffective.

Turkey's membership process retains its uncertainty, as it is still unclear when Turkey will be able to begin actual accession negotiations, despite the Turkish parliament's crucial decisions to amend the Constitution in line with the EU accession criteria in the hope of obtaining a date during the Copenhagen European Council. Before the adoption of these reforms, the Commissioner for Enlargement, Günter Verheugen, signaled that the European Commission was against politically motivated 
bargaining with respect to Turkey, underlining that Turkey was still lagging behind in fulfilling the political criteria of membership. ${ }^{57}$ Hence, Verheugen has played down the raised expectation of a date for accession negotiations at the upcoming Copenhagen European Council even if Turkey would adopt a positive attitude on the issues of Cyprus and NATOESDP (European Security and Defense Policy) cooperation. ${ }^{58}$ On the other hand, the June 2002 Seville European Council noted, "New decisions could be taken in Copenhagen on the next stage of Turkey's candidature in the light of the developments in the situation between the Seville and Copenhagen European Councils." ${ }^{59}$ This could well be interpreted as encouragement and support of Turkey's EU membership efforts.

As for Cyprus, the question seems to be more whether it will join the EU as a unified island or not rather than whether Cyprus will be included in the first wave of enlargement. The answer to that question will depend on whether the direct talks, started between the Greek and Turkish Cypriot leaders in January 2001, will finally lead to the surpassing of the antagonisms between the two communities in Cyprus. Even though the pressure on the parties to arrive at a resolution is stronger than ever, it is uncertain whether the two sides will be able to agree on a settlement. If one thing is clear, though, it is that any eventual settlement will be far from the ideal solution each side envisages for Cyprus. The challenge, as always, is to accept compromises, however painful they might be, as they are essential for arriving at a solution.

The prospect of accession of Cyprus to the EU has not served as a catalyst for the settlement of the Cyprus problem, as was hoped by many. Nevertheless, one cannot ignore the fact that "the approaching EU deadline for the accession of the Republic of Cyprus was one of the critical factors inducing the Turkish Cypriot and Turkish sides to re-embark upon a peace process." ${ }^{\circ 0}$

Many in Europe hoped that the significance of the relations between Turkey and the EU and the aspirations of Turkey of becoming a member of the EU would lead Turkey to change its Cyprus policy so as to bring about a solution in Cyprus. Accordingly, the Greek Cypriots believed that the EU could force Turkey to contribute to the solution of the Cyprus problem through the membership process to the EU. The resolutions by EU organs linking Turkey's accession to the settlement of the Cyprus issue have thus encouraged the Greek Cypriots who already firmly believed that "the key to a solution in Cyprus is Ankara." ${ }^{\circ 1}$ Greek Cypriots, as well as others, anticipated that Turkey would finally be obliged to change its intransigent stance and abandon the Turkish Cypriots in order to ameliorate its international image and be accepted to the European club. ${ }^{62}$ 
Turkey has had difficulty meeting the political requirements since its accession partnership agreement was signed in March 2001. Even though there have been significant amendments of legislation, the problem lies at the level of implementation. Moreover, due to the economic crisis the country has experienced as of the end of 2000, the economic criteria have also become a problematic area. Turkey is thus in urgent need of working seriously on its membership track. As nobody is forcing Turkey to become a member of the EU, it is up to Turkey now to prove the seriousness of its European vocation. It is time to take concrete measures, and the Cyprus question could be the easiest to tackle if Turkish leaders realize (or perhaps decide) where their real interest lies.

Furthermore, it is up to Turkey to transcend its national pride, ${ }^{63}$ which is incompatible with its vocation to join the EU. It is Turkey that aspires to become a member of the European club; it is thus Turkey that has to adapt itself to the values of this club. Clearly, this adaptation requires also a reorientation of its political attitudes. ${ }^{64}$

After all, the prospect of EU accession necessitates a fundamental change of vision, especially concerning policies based on a traditional perception of national sovereignty. Today, sovereignty depends very much on the inter-subjective relations between states: states are sovereign only through their counterparts; it is the "other," through its behavior or acts, which determines sovereignty or the "degree" of sovereignty. ${ }^{65}$ This applies to Turkey as well as for the both parties in Cyprus. All three parties need to embrace the principles of the EU if they see their future in the Union, where even the smallest countries prosper without regretting the loss of sovereignty membership entails. ${ }^{66}$

\section{POSTSCRIPT}

Following the November 2002 parliamentary elections in Turkey, the new Justice and Development Party (Adalet ve Kalkınma Partisi-AKP) government has been advocating policy change with respect to Cyprus. The AKP leader Erdoğan's public statements mark a departure from the previous Turkish policy of passive support for the negotiations towards a settlement in Cyprus. Acknowledging that "no-solution is not a solution," 67 the government wants the Cyprus issue resolved. Erdoğan has also recognized the link between the Cyprus issue and Turkey's EU membership and tried to convince EU officials and member states that giving a date for Turkey's accession negotiations would pave the way to settlement in Cyprus. 
After Kofi Annan presented the Basis for Agreement on a Comprehensive Settlement of the Cyprus Problem on November 11, 2002 the Turkish government has actively encouraged the TRNC President Denktaș to accept the plan as a basis for further negotiations. ${ }^{68}$ In view of the concerns expressed by the two sides, Annan presented a revised proposal on December 10, 2002. If both sides had signed this, then the Copenhagen Council Conclusions would have referred to the "United Cyprus."

The agreement was not signed, the Copenhagen Council announced, as expected, that Cyprus would become a member of the EU on May 1, 2004. February 28, 2003 has been set as the final date for arriving at a comprehensive settlement of the Cyprus problem. In case of a settlement, the Council, acting by unanimity on the basis of proposals by the Commission, shall decide upon adaptations of the terms concerning the accession of Cyprus to the EU with regard to the Turkish Cypriot community. In the absence of a settlement, the application of the acquis to the northern part of the island shall be suspended, until the Council decides unanimously otherwise, on the basis of a proposal by the Commission. ${ }^{69}$

Despite the legislative reforms passed and the declared commitment of the new government to EU membership, Copenhagen failed to give any definite perspective on Turkey's membership track. It only asserted that the EU will open accession negotiations if the European Council in December 2004 decides, on the basis of a recommendation by the Commission, that Turkey fulfills the Copenhagen criteria. ${ }^{70}$

It remains to be seen whether a settlement will be reached by the February 28, 2003 deadline. So far, the Greek Cypriot side has appeared willing to sign the agreement despite the fact that recent public opinion surveys in the RoC have shown that 59 percent of the Greek Cypriot population would vote against the "Annan Plan" if a referendum were to take place now. ${ }^{71}$ The forthcoming February 7, 2003 presidential elections in the RoC also constitute a pressing reason to agree on a settlement sooner rather than later, as it cannot be guaranteed that the successive president will be equally prepared to sign the agreement, given public opinion.

Even though the Turkish Cypriot side has expressed its willingness to negotiate a final settlement on the basis of the revised Annan Plan, it still has some major reservations about the proposal. However, opinion polls indicate that 51.5 percent of Turkish Cypriots approve of the plan. ${ }^{72}$ The legitimacy of Denktass is thus increasingly questioned, while civil society groups in the TRNC demonstrate en masse in support of the Annan Plan. ${ }^{73}$

The current Turkish government is evidently committed to reform in view of EU membership and Cyprus constitutes one of the first obstacles to 
overcome. It is still uncertain whether the Turkish government's moderate stance will prevail over the traditional Cyprus policy favored by the Turkish Foreign Ministry and the current Turkish Cypriot leadership. The press statement by the Turkish Foreign Ministry on December 18, 2002 was very much in line with the longstanding Turkish position. ${ }^{74}$ Remarkably, the statement also declared that Turkey does not accept the Copenhagen Conclusions with regard to Cyprus on legal and political grounds. Obviously, the extensive public debate on Cyprus will continue; only time will tell if the outcome will bring the winds of change or keep the status quo.

\section{CHRONOLOGY}

February 11, 1959: Zurich Agreements signed between the United Kingdom (UK), Greece, and Turkey about the founding principles of the Republic of Cyprus (RoC).

February 19, 1959: London Agreements signed between the UK, Greece, and Turkey about the founding principles of the RoC.

August 16, 1960: Proclamation of the independence of the RoC.

September 12, 1963: Association Agreement (the Ankara Agreement) signed between Turkey and the EU.

November 30, 1963: Archbishop Makarios proposed to his vice president, Fazıl Küçük, 13 amendments that would facilitate the functioning of the state apparatus, as the inapplicability of several dispositions of the Constitution had been proven in the eyes of Greek Cypriots.

December 21, 1963: "Bloody Christmas" is claimed to have caused the death of two Turkish Cypriots, murdered by Greek Cypriot policemen, aimed to force Turkish Cypriots to accept the 13 constitutional amendments. Following these events, the Turkish Cypriots abandoned their places in the parliament and the administration.

March 4, 1964: The United Nations (UN) Security Council passed Resolution 186 (1964), which stationed a force-the UNFICYP (United Nations Peacekeeping Force in Cyprus) - for maintaining peace and putting an end to violence in Cyprus. The reference in this resolution to the "Government of the Republic of Cyprus" marked the first instance of the recognition of the Greek Cypriot administration as the legal government of Cyprus. 
December 1, 1964: Association Agreement between Turkey and the EU came into force.

December 19, 1972: Association Agreement between the Republic of Cyprus and the EU signed.

June 1, 1973: Association Agreement between the Republic of Cyprus and the EU came into force.

July 15, 1974: Coup d'état organized by the Greek military junta in power and executed by EOKA-B (the Greek acronym for "the national organization of Cypriot fighters") against President Makarios.

July 20, 1974: Turkish intervention in Cyprus to prevent enosis, to put an end to inter-communal fighting and to save the Turkish Cypriots.

August 16, 1974: Second offensive move by the Turkish army, which led to the occupation of 37 percent of the northern part of the island by the Turkish army and subsequently to the territorial regrouping of the populations of the two communities.

February 13, 1975: Proclamation of the establishment of the Turkish Cypriot Federal State (Kıbrıs Türk Federe Devleti).

February 12, 1977: High-level Agreement between President Rauf Denktaș and Archbishop Makarios setting the basis for the inter-communal talks.

May 19, 1979: Ten-point Agreement between Presidents Rauf Denktaş and Spyros Kyprianou setting the basis for the inter-communal talks.

November 15, 1983: Proclamation of independence of the Turkish Republic of Northern Cyprus (Kuzey Kıbrıs Türk Cumhuriyeti-TRNC). Only Turkey recognizes the TRNC, whereas the RoC, which only controls the Southern zone and includes only the Greek Cypriots, Maronites, Armenians, and other minorities, is recognized as the sole legitimate state by all other states.

November 18, 1983: The UN Security Council adopts Resolution 541 (1983), which deplores this declaration of secession, considers the proclamation invalid, and demands its annulment and calls for all the states to recognize no other state than the Republic of Cyprus. 
April 14, 1987: Application for full membership to the EU by Turkey.

January 1, 1988: Customs union protocol between the Republic of Cyprus and the EU came into force.

December 18, 1989: Opinion of the European Commission rejected the Turkish application but confirmed the eligibility of Turkey for membership.

July 4, 1990: Application for full membership to the EU by the government of the Republic of Cyprus in the name of the whole island.

June 30, 1993: European Commission's opinion in favor of the opening of accession negotiations with Cyprus.

October 4, 1993: European Council approves the Commission's opinion during its summit in Luxembourg.

June 24-25, 1994: European Council of Corfu declared that the next enlargement of the Union would encompass Cyprus and Malta.

March 6, 1995: The "historical compromise" that guaranteed Cyprus its accession negotiations would begin six months after the conclusion of the 1996 IGC. In return, Greece lifted its veto on the customs union agreement with Turkey.

January 1, 1996: Entry into force of the Customs Union between the EU and Turkey.

December 12-13, 1997: The decision to start negotiations with the RoC taken by the European Council of Luxembourg.

March 12, 1998: The Greek Cypriot President, Glafcos Clerides, invited the Turkish Cypriot community to join the Cypriot negotiation team. The British Presidency of the EU transmitted the invitation extended to Turkish Cypriot leaders during the European Conference in London. The invitation was refused by the TRNC.

March 31, 1998: Accession negotiations started with the RoC.

November 10, 1998: Beginning of substantial negotiations for accession with the RoC. 
December 10-11, 1999: European Council Helsinki summit asserted that the political settlement in Cyprus would not constitute a precondition for the accession of Cyprus to the European Union; the candidacy of Turkey made official after Greece lifted its veto.

December 4, 2001: Decision to start face-to-face talks between Presidents Denktaş and Clerides.

December 14-15, 2001: European Council meeting in Laeken expressed its determination to bring the accession negotiations to a successful conclusion - by the end of 2002 - with those countries that will be ready, and listed Cyprus as one of the countries which could be ready if the present rate of negotiations and reforms is maintained.

January 21, 2002: Beginning of intensive and open-ended rounds of negotiations between the Greek and Turkish Cypriot leaders.

November 11, 2002: UN Secretary General Kofi Annan presented the Basis for Agreement on a Comprehensive Settlement of the Cyprus Problem.

December 12-13, 2002: European Council of Copenhagen welcomed Cyprus as a member of the EU from May 1, 2004 regardless of the resolution of the Cyprus issue.

\section{NOTES}

1. The European Community became the European Union on November 1, 1993, with the Maastricht Treaty. The term European Union (EU) will be used throughout the essay for the sake of simplicity.

2. Interview with Kostas I. Hatzidakis, Alternate Member of the Committee of Foreign Affairs, Human Rights, Common Security and Defense Policy, European Parliament, Strasbourg, June 14, 2000.

3. Words of a Spanish diplomat (who spoke on the basis of confidentiality) during an interview at the Permanent Representation of Spain to the European Union, Brussels, May 18, 2000.

4. The analysis here is based on the literature on the issues in question, the coverage of these issues in the Turkish, Cypriot, Greek, and European press, as well as interviews conducted in 2000 in Cyprus, Brussels, Strasbourg, and Paris with politicians, European bureaucrats, diplomats, and academics, within the framework of the master's thesis project of the author. Since 2001, the author's involvement within the TESEV (Turkish Economic and Social Studies Foundation) project on Cyprus has confirmed the findings of these interviews via encounters in Turkey, Cyprus and Europe during related conferences and meetings.

5. Marie-Pierre Richarte, "La question chypriote dans la politique étrangère de la Turquie," Trimestre du monde, Vol.4, No.36 (Oct.-Dec. 1996), p.105.

6. Words of Kürşat Eser, Nationalist Action Party member of the Turkish Grand National Assembly at the "Conference on Cyprus' Accession to the European Union" on May 4, 2002 
at Boğaziçi University, Istanbul.

7. Confidential interview with an official at the Embassy of Turkey, Paris, July 17, 2000.

8. Hansjörg Brey, "Turkey and the Cyprus Question," International Spectator, Vol.14, No.1 (Jan.-March 1999), p.111.

9. Richarte (1996), p.107.

10. Maurice H. Mendelson, EU and Cyprus: An Expert View - Opinion on the Application of Republic of Cyprus to Join the European Union (Lefkoșa, 1997).

11. Christian Heinze, On the Question of the Compatibility of the Admission of Cyprus into the European Union with International Law, the Law of the EU and the Cyprus Treaties of 1959/60, Appraisal study presented to the Republic of Turkey (Munich, March 1997).

12. Interview with Georges Vandersanden (Lawyer, Professor at the Université Libre de Bruxelles, Brussels), May 16, 2000. One should note that the treaty establishing Austria, which assigned it a status of neutrality in order to prevent its union with Germany, did not constitute an obstacle to Austria's accession to the EU in 1995.

13. Le Monde, Dec. 25, 1993.

14. Interview with Ferdi Sabit Soyer, Secretary General of CTP (Cumhuriyetçi Türk PartisiRepublican Turkish Party), Lefkoșa, April 6, 2000.

15. It is worth noting that Cyprus is the most militarized island in the world. For further information on this and the crisis over the S-300 missiles, see Madeleine Demetriou, "On the Long Road to Europe and the Short Path to War: Issue-Linkage Politics and the Arms Buildup on Cyprus," Mediterranean Politics, Vol.3, No.3 (Winter 1998), pp.38-51.

16. Christophe Chiclet, "Chypre aux portes de l'Union européenne," Politique Internationale, No.77 (Autumn 1997), p.116.

17. Sabahattin İsmail, 150 Soruda Klbris Sorunu [The Cyprus Problem in 150 Questions] (Istanbul: Kastaş Yayınevi, 1998), pp.362-3.

18. Korkmaz Haktanır, A Time to Remember (Gazimağusa: Eastern Mediterranean University Center for Cyprus Studies Publications, 1999), pp.28-34.

19. Erol Manisalı, Dünden Bugüne KIBRIS [CYPRUS from Past to Present] (Istanbul: Çağdaş Matbaacilık ve Yayıncilık, 2000), p.120.

20. European Council of Luxembourg, Presidency Conclusions, Dec. 12-13, 1997.

21. Briefing of the Turkish Minister of Foreign Affairs in Kathimerini (English Edition), Nov. 3-4, 2001.

22 Ibid.

23. Cyprus Mail, Nov. 6, 2001.

24. Ibid.

25. Jacques F. Poos (Rapporteur), Report on Cyprus's Application for Membership to the European Union and the State of Negotiations (European Parliament, Committee on Foreign Affairs, Human Rights, Common Security and Defense Policy, July 17, 2001).

26. Christopher Preston, Enlargement and Integration in the European Union (London: Routledge, 1997), p.22.

27. Confidential interview with an official at the French Ministry of Foreign Affairs, Paris, June 7 , 2000.

28. Ibid.

29. Interview with Dimitrios Triantaphyllou, Research Fellow at the Institute for Security Studies of the European Union, Paris, July 21, 2000. The opinions expressed are the personal views of the interviewee and do not represent the views of the Institute.

30. See the Report of the Commission of the European Communities, Jan. 27, 1976, quoted in Semih Vaner, “Chypre et l'Union européenne," Politique Étrangère, $61^{\mathrm{e}}$ année, No.3 (Autumn 1996), p.660.

31. Panos Tsakaloyannis, "The European Community and the Greek-Turkish Dispute," Journal of Common Market Studies, Vol.19, No.1 (1980), p.52.

32. Mehmet Uğur, The European Union and Turkey: An Anchor Credibility Dilemma (Aldershot: Ashgate, 1999), p.20.

33. See the resolutions of the European Parliament of July 8, 1982, July 10, 1986, July 9, 1987, and Dec. 15, 1988 in La Position européenne sur Chypre (Nicosia: Republic of Cyprus Press and Information Bureau, 1998), pp.68, 82, 84, 89.

34. Uğur (1999), p.21. 
35. Ibid., p.163.

36. The prosperity of the Republic of Cyprus is another factor that obstructs the idea of enosis with Greece. Greek Cypriots are currently richer and better administered compared to their counterparts in Greece.

37. Confidential interview with a diplomat at the Embassy of the Netherlands, Paris, June 19, 2000.

38. Confidential interview with an official at the Permanent Representation of Greece to the EU, Brussels, May 18, 2000.

39. See the Bulletin Quotidien Europe of Nov. 9-10, 1998 (No.7339) for the declaration of the Turkish Minister of Foreign Affairs following the first regular progress report of the European Commission on Turkey's accession process, released on Nov. 4, 1998.

40. According to Andrew Apostolou, this affair was the work of two politicians outside the EU: Tansu Çiller, the Turkish prime minister at the time, and Glafcos Clerides, the President of the Republic of Cyprus. The two supposedly concluded a deal through indirect channels. During a visit to London just before the elections in Turkey, Çiller spoke to Tony Blair, who was the leader of the opposition Labour Party at the time, and said that the Socialist Group in the European Parliament (EP) should vote in favor of the customs union with Turkey. Otherwise, she warned, the Islamists would come to power. At the same time, Clerides is said to have contacted the Labour Party and told them that the Socialist Group of the EP, with whom the Greek Cypriot community in the UK has close links, should vote in favor of the customs union with Turkey because he had made a deal with Çiller. See Andrew Apostolou, "Turkey, the European Union, and Cyprus," Mediterranean Quarterly, Vol.10, No.4 (Fall 1999), pp.120-21.

41. Ibid.

42. Confidential interview with an official of the European Commission, DG Enlargement, Cyprus Team, Brussels, May 15, 2000.

43. Confidential interview with an official at the Permanent Representation of Italy to the EU, Brussels, May 15, 2000.

44. Helsinki European Council, Presidency Conclusions, Dec. 10-11, 1999.

45. Seville European Council, Presidency Conclusions, June 21-22, 2002.

46. Confidential interview with an official at the Permanent Representation of Greece to the EU, May 18, 2000.

47. John Redmond, The Next Mediterranean Enlargement of the European Community: Turkey, Cyprus and Malta? (Aldershot: Dartmouth, 1993), p.54.

48. Jacques F. Poos (Rapporteur), Report on Cyprus's Application for Membership to the European Union and the State of Negotiations (European Parliament, Committee on Foreign Affairs, Human Rights, Common Security and Defense Policy, Sept. 19, 2000). Nevertheless, the EU is ready to accept any settlement of the Cyprus problem reached by both parties in Cyprus. Verheugen declared in March 2000 during a visit to Cyprus that the existence of foreign troops did not constitute an obstacle to the accession of Cyprus.

49. Confidential interview with an official of the European Commission, DG Enlargement, Turkey Team, Brussels, May 16, 2000.

50. Interview with Kostas I. Hatzidakis.

51. Interview with a diplomat at the Permanent Delegation of Turkey to the European Union, Brussels, May 16, 2000.

52. The United States imposed an arms embargo on Turkey following the Turkish intervention of 1974 due to the pressure of the Greek lobby of the American Congress and despite the cold war; the embargo lasted for three years. This decision led Turkey to realize its isolation: it could not even count on its allies. At this point Turkish foreign policy was revised and Turkey began to search for other partners, such as the USSR and Middle Eastern countries. From that point on, the construction of military might that would allow Turkey to defend itself alone was emphasized.

53. Jean-François Drevet, Chypre île extrême: Chronique d'une Europe oubliée (Paris: Syros/Alternatives, 1991), p.305.

54. For example, the decision of the European Council (Laeken, Dec. 2001) to include Turkey in the European Convention on the Future of Europe alongside the other candidate countries, even though Turkey was not accounted for in the modifications brought about by the Treaty of 
Nice in 2000.

55. Confidential interview with an official of the European Commission, DG Enlargement, Turkey Team.

56. Interview with Fatma Azgın (Pharmacist, Participant of bi-communal activities), Lefkoşa, April 6, 2000.

57. See the briefing of Günter Verheugen, "Öncelik Kıbrıs değil siyasi kriterler" [Priority political criteria, not Cyprus], Frankfurter Allgemeine Zeitung, July 1, 2002, $<$ http://www.ntvmsnbc.com/news/161330.asp>.

58. The EU would like to use NATO assets for the planned European rapid reaction force. Turkey has blocked this because of differences with Greece. Some argue that the whole concept of the ESDP will be under threat unless the row is resolved. See <http://news.bbc.co.uk/ 1/hi/uk_politics/2162493.stm>.

59. Seville European Council, Presidency Conclusions.

60. Nathalie Tocci, "Cyprus and the EU: Catalyst for Negotiations or Settlement?," Turkish Policy Quarterly (Spring 2002), p.48.

61. Interview with Georges Zodiates, Counselor at the Permanent Delegation of the Republic of Cyprus to the European Union, Brussels, May 17, 2000. The Greek Cypriot argument is that if Ankara decides to solve the problem the Turkish Cypriot leaders will follow the Turkish line without question. The Commissioner for Enlargement, Günter Verheugen, has also commented that the key to a solution in Cyprus was in Ankara's hands, adding that the standpoint of the Turkish army was not clear either. See Verheugen's briefing to Frankfurter Allgemeine Zeitung.

62. Tozun Bahcheli and Nicholas X. Rizopoulos, "The Cyprus Impasse: What Next?, World Policy Journal, Vol.13, No.4 (Winter 1996/97), p.32.

63. Confidential interview with an official at the Permanent Representation of Spain to the EU.

64. Preston (1997), p.29.

65. Bertrand Badie, "La Souveraineté sur la scène mondiale: concept reconsidéré ou fiction renouvelée?," La Revue Tocqueville/Tocqueville Review, Vol.19, No.2 (1998), p.7.

66. Interview with Jacques F. Poos (Questeur), Member of the Committee of Foreign Affairs, Human Rights, Common Security and Defense Policy, Strasbourg, June 14, 2000. Poos gave the example of his own country, Luxembourg, stating that it felt itself at ease within the EU. In other words, it lost nothing by transferring a part of its sovereignty to the EU.

67. Fikret Bila, “Erdoğan'ın Kıbrıs’a bakışı,” Milliyet, Dec. 18, 2002.

68. Details of the Annan Plan, including revisions, are available at <http://www.pio.gov.cy/other/ revised_un_Plan.pdf $>$.

69. European Council of Copenhagen, Presidency Conclusions, Dec. 12-13, 2002, Articles 11-12.

70. One wonders why the EU has opted for this December 2004 date, as the Commission publishes its regular report on candidate countries each autumn. Perhaps the dates rest on the presumption that Turkey will not fulfill the political criteria by the end of 2003 ? Even though the Turkish government interpreted this date optimistically as a clear commitment on the part of the EU, as the conclusions promise to open accession negotiations without delay, the Commission and the Council will eventually decide whether Turkey has addressed its shortcomings, not only with regard to legislation but also implementation.

71. 'Opinion poll by 'Politis' and 'Ortam' Newspapers on Annan's Plan: Turkish Cypriots approve by $51 \%$, Greek Cypriots still opposed by 59\%", at <http://www.european-cyprus.net/ cgibin/hweb?-A=760\&-V=from_the_press \&w=>.

72. Ibid.

73. Some have also suggested that a referendum be held right away in order to act according to the demands of the Turkish Cypriot population. For articles on civil movements and views, see Klbrls, Dec. 25, 2002.

74. The contents of this statement are available at <http://www.mfa.gov.tr/turkce/gruopc/ca/ 2002/12/default.htm>. 